\title{
PENDIDIKAN ERA 21 DAN ADOPSI MODEL PEMBELAJARAN (KAJIAN PADA PEMBELAJARAN PENDIDIKAN TEKNIK ELEKTRONIKA)
}

\author{
Darlan Sidik \\ Pendidikan Teknik Elektronika, FT UNM \\ e-mail darlan@unm.ac.id
}

\begin{abstract}
Abstrak
Penyelenggaraan pendidikan era 21 membutuhkan berbagai kompetensi dan keterampilan yang harus dikuasai peserta didik agar menjadi individu yang sukses dalam persaingan pengetahuan dan keterampilan. Keterampilan yang diperlukan era 21 dikenal dan relevan dengan empat pilar kehidupan mencakup learning to know, learning to do, learning to be, dan learning to live together. Prinsip ini mengandung keterampilan khusus yang perlu diintegrasikan dalam pelaksanaan pembelajaran adalah; keterampilan berpikir, literasi informasi, pemecahan masalah, kolaboratif menggunakan model pembelajaran problem, proyek dan invensi dalam praktek pembelajaran era industrialisasi sebagai katalisasi model pembelajaran era pengatahuan. Adopsi pembelajaran teknik elektronika yang dikaji dengan mengintegrasikan model pembelajaran yang berfokus pada peserta didik sebagai prinsip pokok, adopsi model pembelajaran yang sesuai dengan komponen pembelajaran era 21 adalah (1) pembelajaran Project Based Learning, (2) Problem Based Learning, (3) Pembelajaran berbasis Teknologi Informasi. Adopsi model pembelajaran diintegrasikan dengan internet sebagai sumber belajar sangat penting untuk mewujudkan masa depan peserta didik yang lebih baik dan mampu berkompetisi pada dunia usaha dan dunia industry di era mendatang.
\end{abstract}

Kata Kunci: Keteramiplan era 21, Model Pembelajaran, Elektronika.

\begin{abstract}
The implementation of 21 st era education requires various competencies and skills that must be mastered by students in order to become successful individuals in the competition of knowledge and skills. The skills needed in the 21st era are known and relevant to the four pillars of life including learning to know, learning to do, learning to be, and learning to live together. This principle contains special skills that need to be integrated in the implementation of learning are; thinking skills, information literacy, problem solving, collaborative use of problem learning models, projects and inventions in the learning practices of the industrialization era as a catalyst for learning models of knowledge era. The adoption of learning electronic techniques that are studied by integrating learning models that focus on students as the main principle, the adoption of learning models that are in accordance with the learning component of the 21 st era are (1) learning Project Based Learning, (2) Problem Based Learning, (3) Learning based Information Technology. Adoption of learning models integrated with the internet as a source of learning is very important to realize the future of students who are better and able to compete in the business world and the industrial world in the coming era.
\end{abstract}

Keywords: 21st era skill, Learning Model, Electronics. 


\section{PENDAHULUAN}

Pendidikan era 21 menjadi fokus kajian dan diskusi mendalam pada berbagai kalangan dan lebih khusus lagi pada pengkaji pendidikan di sekolah akhir-akhir ini. Pandangan setiap individu terhadap era ini sangat beragam. Sebagian kelompok individu menanggapi dengan serius dan sebagian lainnya menanggapi biasa-biasa saja, serta sebagian lagi tidak merespon atau tidak menjadi masalah dalam kehidupannya. Kondisi yang demikian, individu perlu mendapat ruang pengayaan tentang kemungkinan untuk menjawab tatanan kehidupan di masa datang yang tidak dapat diprediksi secara tepat. Kenyataan ini dapat di kelolah dengan melakukan beberapa pendekatan, salah satu pendekatan yang efektif digunakan adalah melalui model pembelajaran yang adaptif di sekolah. Pandangan kelompok individu yang beragam pada lembaga pendidikan atau persekolahan perlu mendapat perhatian. Pertanyaan yang besar pada pendidikan era 21, Apakah kita sudah cukup memahami ragam keterampilan era 21?, Apakah penyelenggara pembelajaran pendidikan teknik elektronika sudah memahami bagaimana model pembelajaran yang sesuai dalam rangka menyiapkan peserta didik untuk menguasai keterampilan era 21?, Bagaiman mengitengrasikan model pembelajaran dengan teknologi?. Dengan pertanyaan yang besar ini dapat memberikan kajian akademik untuk menjadi bahan pemikiran bersama pada pembelajaran teknik elektronika FT UNM.

Kajian emprik menunjukkan bahwa tamatan sekolah menengah hingga perguruan tinggi masih sangat kurang kompeten pada beberapa hal seperti; (1) komunikasi oral maupun tulis, (2) berpikir kritis dan pemecahan masalah, (3) lemah dalam bekerjasama atau kolaborasi dan (4) belum mampu bekerja secara professional menggunakan teknologi (Trilling, 2009).

Hasil kajian lain, menunjukkan, bahwa Indonesia memiliki tenaga kerja dengan kompetensi keahlian yang rendah dan upah murah jika dibandingkan dengan Negara Filipina dan bangsa Indonesia tidak akan mampu bersaing dan akan kehilangan kesempatan kerja yang ada disekelilingnya, jika tidak didukung dengan program pembelajaran yang menghasilkan luaran capaian dengan keterampilan tinggi. Bidang pekerjaan baru yang muncul era 21 ditandai dengan komponen yang terkandung dalam revolusi industri 4.0 (literasi TIK, literasi data, dan literasi manusia). Literasi TIK dan litersi data menuntut kompetensi karakteristik pembelajaran prosedural, dan literasi manusia menuntut jiwa kreatif dan inovatif dengan level kognitif tinggi (evalasi dan kreasi) (Scoot, 2015).

Keterampilan yang dibutuhkan oleh lulusan perguruan tinggi agar dapat bersaing untuk bekerja di era 21 adalah informasi, kolaboratif, innovasi, dan kecepatan kerja yang spesifik menjadi aspek yang penting di tumbuhkan dalam pembelajaran. Peserta didik tidak lagi difokuskan untuk melakukan tugas-tugas manual yang harus diselesaikan berdasarkan kurikulum yang telah dirumuskan. Indikator hasil pembelajaran yang diperlukan adalah kemampuan berkumunikasi, berbagi, dan menggunakan tknologi informasi untuk memecahkan masalah yang kompleks, beradaptasi dan berinnovasi dalam 
menanggapi tuntutan baru dan memperluas teknologi untuk menciptakan pengetahuan baru melalui lembagan pendidikan

Kajian ini difokuskan pada komponen keterampilan pembelajaran yang diperlukan pada era 21. Lembaga pendidikan/ persekolahan ditantang untuk menemukan model dan strategi pembelajaran agar peserta didik sukses dan berhasil dalam bekerja menjalani kehidupan melalui penguasaan: keterampilan berpikir kreatif, pemecahan masalah, kolaboratif, inovatif, dan kratif. Pendidikan era 21 menghasilkan keterampilan yang sesuai dengan kebutuhan kerja diintegrasikan dalam model pembelajaran agar peserta didik mencapai transfomrasi pengetahuan yang diperlukan untuk bekerja dimasa datang.

\section{KERANGKA KERJA PEMBELAJARAN ERA 21}

$\begin{array}{llr}\begin{array}{c}\text { Lembaga } \\ \text { merumuskan }\end{array} & \text { pendidikan telah } \\ \text { kompetensi } & \text { dan }\end{array}$ keterampilan yang diperlukan menghadapi era 21. Hal yang perlu mendapat perhatian adalah memberi pengalaman belajar peserta didik di era 21 tidak cukup hanya melalui satu pendekatan. Beberapa kajian telah dilakukan dan sangat bersesuaian dengan kebutuhan pembelajaran. Kompetensi dan keterampilan yang dibutuhkan peserta didik dalam menghadapi kehidupan dan dunia kerja dan dunia industri (DUDI) diutamakan beberapa keterampilan, seperti: (1) Kemampuan berpikir kritis dan pemecahan masalah,

(2) Terampil berinteraksi dan adaptasi,

(3) kolaboratif dan kepemimpinan, (4) Inisiatif dan berjiwa intepreneur, (5) keterampilan berkomunikasi secara oral maupun tulis, (6) keterampilan mengakses intormasi, dan (7) memiliki ingin tahu dan imajinasi (Wagner, $\mathrm{T}$, 2010). Selanjutnya, keterampilan tersebut masih memerlukan penguatan keterampilan lainnya agar tuntutan kompetensi yang harus dimiliki peserta didik sesuai dengan harapan yang diperlukan agar mereka dapat berinteraksi dengan baik, penguatan keterampilan yang dimaksud yaitu; keterampilan berpikir kritis, komunikasi, kepemimpinan, kolaborasi, daya adaptasi, produktif, akuntabilitas, inovasi, dan kemampuan mengakses, menganalisis, serta mensintesis informasi dengan sempurna (Barry,.2012). Hasil penelitian lain mendeskripsikan bahwa ada dimensi belajar yang diperlukan pada pembelajaran era 21 adalah: informasi, komunikasi, etika, dan pengaruh social serta lingkungan, kreativitas juga merupakan salah satu dimensi penting agar peserta didik sukses menghadapi dunia yang kompleks (Ananiadou, 2009).

Tulisan lain menunjukkan bahwa kompetensi yang harus diperoleh peserta didik dalam proses pembelajaran yang di kenal dengan 4Cs adalah: communication, collaboration, crtical thinking, dan creativity. Komptensi tersebut penting dirancang dan diajarakan pada peserta didik dalam kontek kompetensi esensial (dasar) agar peserta didik lebih siap menghadapi tuntan kompetensi yang di perlukan. Untuk mencapai tuntutan kompetensi tersebut di perlukan beberapa komponen penguatan kompetensi mencakup; kreativitas, inovasi, berpikir kritis, pemecahan masalah, dan mengambilan keputusan yang melekat secara professional dalam diri peserta didik. Way of working 
merujuk keterampilan berkomunikasi, berkolaborasi, dam yang tidak kalah pentingnya adalah tools for working yang berorientasi pada adanya kesadaran peserta didik secara global maupun lokal untuk dapat mengembangkan karir dan tanggunjawab yang tinggi sebagai pribadi maupun social. Untuk melengkapi kompetensi diperlukan dukungan sistem teknologi diperlukan penguatan literasi informasi dan penguasaan komunikasi baru untuk belajar dan bekerja melalui system jaringan teknologi digital (Griffin, , 2012 ).

Penguatan pendidikan era 21 yang diintegrasikan dalam proses pembelajaran memerlukan kerangka pemikiran yang mendasar dan masih sangat relevan yang dikenal dengan empat pilar pembelajaran (Delors, 2015), dideskripsikan secara sederhana sebagai berikut:

(1) Learning to know belajar dan memperdalam pengetahuan untuk sukses di masa datang. Peserta didik selalu siap belajar ketika menghadapi permasalahan baru dan juga memerlukan keterampilan baru secara interdisipliner dan sesuai dengan tuntan topik pembelajaran era 21 seperti: (a) tumbuhkan kasadaran global, (b) literasi data, (c) TIK, dan (d) literasi manusia atau kewarganegaraan, kondisi ini peserta didik dirahkan untuk memperdalam pengetahuan melalui berbagai rancangan dan strategi pembelajaran yang berlansung di sekolah.

(2) Learning to Do, peserta didik mampu menyesuakan diri dan daya adaptasi serta ketahanmalangan yang tinggi agar peserta didik belajar untuk berkarya dengan pengatahuan akademik dan terapan untuk keterampilan berpikir kritis, kemampuan merancang masalah, komunikasi dan kolaborasin kreatif dan inovasi, literasi tik. literasi data. Proses pemberian pengalaman belajar peserta didik ini menghasilkan daya tahan pribadi yang mampu menghadapi perubahan kehidupan dalam kondisi lingkungan yang tidak dapat dipredisksi bagi setiap individu peserta didik.

(3) Learning to $\mathrm{Be}$ menekankan pada keterampilan kognitif yang diperlukan peserta didik, tapi bukan satu satunya, melainkan diperlukan kompetensi yang mendasar agar peserta didik mampu menghadapi dan mengatasi masalah sulit dimana era dia menjalankan kehidupannya, sehinggan membutuhkan pengalaman belajar keterampilan social dan lintas budaya, tanggungajawab pribadi, pengaturan diri, dan inisiatif, ketrampilan berpikir logis, keterampilan metakognitif, wirausaha dan belajar terus menerus. Dengan demikian peserta didik harua mampu bekerja dan belajar bersama dengan berbagai kelompok untuk berbagai jenis pekerjaan, lingkungan sosial, dan mampu beradaptasi dengan perubahan.

(4) Learning to Live Together. Proses pembelajaran ini memfokuskan pada kegiatan belajar kooperatif agar mencapai keterampilan yang tinggi jika ditinjau berdasarkan tangga domain pengetahuan peserta didik untuk menyimpan informasi dalam jangka waktu panjang. Belajar bersama akan memberikan kesempatan peserta didik terlibat aktif, berdiskusi serta mencapai tujuan pembelajaran pada tarap berpikir kritis atau HOTS (higher order thinking skills). Pijakan ini pendidik merancang pembelajaran yang focus pada belajar kolaboratif sesuai denga kehidupan nyata dan nilai-nilai yang hidup dalam lingkungan belajar, seperti: (1) teamwork 
dan interconnectedness, agar perserta didik mampu mendapatkan nilai lebih dan unggul serta berkembang di lingkungan kerja yang kolaboratif interdesipliner pertukaran idea-idea besar untuk melawan dikriminasi ras/suku dan jenis kelamin, serta usia (Savenda, 2011), (2) Civic dan citizenship literacy, literasi manusia dan masyarakat merupakan keterampilan peserta didik untuk memahami proses interaksi pada tingkat lokal, regional, dan intenasional, agae mereka mandapatkan arti dari sebuah kebersamaan dan menjurus pada proses persaigan yang tidak sehat. Pilar inilah, yang dapat memberikan arah kebijakan peserta didik untuk membangun potensi persaingan, naming yang selalu hadir adalah persandingan atau kesetaraan, (3) kompetensi, peserta didik mampu mengambil tindakan dengan beragam cara dan menganggap mereka sebagai warga dunia dan menggunakan keterampilan berpikir kritis dan mempriritaskan tidakan berdasarkan bukti dan mempertimbangkan efek tindakan yang telah dilakukan.

\section{MODEL PEMBELAJARAN ERA 21 PENDIDIKAN TEKNIK ELEKTRONIKA}

Pergeseran pandangan pembelajaran era 21 dengan hadirnya teknologi informasi komunikasi, otomasi dan literasi merupakan ciri dari peradaban saat ini menjadi sejumlah kemampuan yang harus diperoleh peserta didik dalam proses pembelajaran. Pergeseran paradigm belajar era 21, merupakan interaksi antara karkteristik pembelajaran 21 dengan model pembelajaran (Litbang Dikbud, 2019), dapat dideskripsikan sebagai berikut:
1. Informasi, model pembelajaran yang diarahkan untuk mendorong peserta didik mencari tahu pada berbagai sumber belajar secara sukarela atau tanpa diberitahu.

2. Komputasi, model pembelajaran diarahkan untuk mampu merumuskan masalah, bukan hanya menyelesaikan masalah secara sepat dengan menggunakan mesin pencari sumber.

3. Otomasi,model pembelajaran diarahkan untuk melatih berpikir analisis, . sintesis dan evaluasi untuk mengambil keputusan, tidak berpikir mekanis

4. Komunikasi, model pembelajaran menekankan pentingnya kerjasama dalam menyeesaikan masalah dari mana dan kemana saja.

Keempat interaksi di atas merupakan pandangan pembelajaran yang berpusat peserta didik (Student Centred Learning) menjadi Teacher as Fasilitator, Guide, and Consultant. Interaksi yang demikian merupakan arah pembelajaran agar pendidik selalu menempatkan dirinya sebagai fasilitator. Hal ini wajar karena sumber belajar yang dapat dirujuk peserta didik tidak hanya dari pendidik melainkan dari banyak sumber belajar.

Efek dari pembelajaran era 21 adalah penerapan teknologi pembelajaran menggunakan desain atau medel pembelajaran yang tepat, agar hasil belajar yang ingin dicapai dapat bersesuaian dengan tujuan dan proses pembelajaran di era pengetahuan. Pendidikan teknik elektronika menempatkan hasil pembelajaran 
didorong menghasilkan produk melalui kegiatan merancang; merumuskan job, merancang, menghitung, dan melaksanakan serta mengevaluasi hasil dari proses.

Bebrapa kajian menunjukkan bahwa model pembelajaran berbasis proyek memiliki ciri-ciri, seperti: (a) peserta didik membuat keputusan dan membuat kerangka kerja sendiri, (b) ada masalah yang berpijak pada kondisi nyata dan kondisi harapan dan pemecahannya tidak diselesaikan di awal kegiatan, (c) Peserta didik bertangungjawab untuk mendapatkan dan mengelola informasi yang terkumpul, (d) melalukan evaluasi secara berkelanjutan dan mereka secara teratur meninjau ulang apa yang telah dikerjakan, (e) hasil akhir pembelajaran berupa produk dan evaluasi kualitasnya, serta kelas berada pada pada lingkungan yang memberi toleransi kesalahan dan perubahan (Ajeyelemi,.1993).

\section{Project Based Learning} merupakan model pembelajaran yang berpijak pada konstruktivitik mengutamakan aktivitas peserta didik dan kolaboratif tentang kegiatan percobaan, studi kasus, diskusi, dan simulasi. Salah satu aktivitas yang banyak dilakukan mahasiswa pendidikan teknik elektronika adalah simulasi berbasis digital, ini dimaksudkan agar mahasiswa dapat mengetahui langsung gejala perjalanan arus dan tegangan dalam sistem rangkaian yang kasat mata. Oleh karena dengan strategi pembelajaran simulasi mahasiswa dapat melalukan lompatan pengetahui yang sesuai dengan tujuan pembelajaran tanpa melihat bentuk fisik dan sitem rangkaian elektronika yang dikaji.
Problem Based Learning, model merupakan strategi pembelajaran menekankan lingkungan belajar peserta didik aktif, kerja kelompok/kolaboratif dengan menggunakan teknik penilaian otentik yang berhubungan dengan kontek social peserta didik, masalah harus berakar pada materi subjek dari kurikulum (Waras Kamdi,. 2008). Ciri utama dari model Problem Based Learning (PBL). (a) PBL merupakan serangkaian aktivitas yang harus dilakukan peserta didik dan tidak hanya mendengar, mencatat, kemudian menghafal materi pelajaran, tetapi melalui model PBL peserta didik menjadi aktif berpikir, berkomunikasi, mencari dan mengolah data, dan akhirnya membuat kesimpulan. (b) aktivitas pembelajaran diarahkan untuk menyelesaikan masalah. Problem based learning ini menempatkan masalah sebagai kata kunci dari proses pembelajaran. Artinya tanpa masalah pembelajaran tidak akan mungkin bisa berlangsung, (c) pemecahan masalah menggunakan pendekatan berpikir secara ilmiah. Model ini digunakan pada saat peserta didik dihadapkan untuk mencari topik tugas penulisan karya ilmiah atau tugas mandiri terstruktur.

Integrasi Model Pembelajaran dengan Teknologi, merupakan strategi pembelajaran yang memanfaatkan sistem jaringan elektronik menggunakan media situs (website) yang bisa di akses melalui jaringan internet (Mohammed Anine Chatti, 2019). Pembeljaran berbasis web atau yang dikenal juga dengan "web Based learning" merupakan salah satu jenis penerapan dari pembelajaran elektronik (e-learning) dengan karakteristik sebagai berikut : 
1. Interactivity (interaktivitas); tersedia jalur komunikasi yang lebih banyak, baik secara langsung (synchrounus), seperti chatting atau messenger atau tidak langsung (asynchrounus), seperti forum, mailing list atau buku tamu.

2. Independency (kemandirian); fleksibilitas dalam aspek penyediaan waktu, tempat, pengajar dan bahan ajar. Hal ini menyebabkan pembelajaran menjadi lebih terpusat kepada siswa ( student-centered learning).

3. Accessibility (aksesibilitas); sumber belajar menjadi lebih mudah diakses melalui pendistribusian di jaringan internet dengan akses yang lebih luas dari pada pendistribusian sumber belajar pada pembelajaran konvensional.

4. Enrichment (pengayaan); kegiatan pembelajaran, presentasi materi kuliah dan materi pelatihan sebagai pengayaan, memungkinkan penggunaan perangkat teknologi informasi seperti video streaming, simulasi dan animasi.

Keempat karakteristik di atas merupakan strategi penyampaian yang bersesuaian dengan pembelajaran era 21 . Penggunaan web merupakan aktivitas belajar yang menggunakan bantuan teknologi elektronik dengan memanfaatkan jaringan internet untuk berkomunikasi dan menyampaikan materi ajar kapan dan dimana saja, tanpa kehadiran pendidik dan peserta didik tetap belajar berdasarkan instruksi yang telah disajikan pada berbagai komponen situs yang ada dalam online. Pembelajaran berbasis web efektif digunakan jika materi ajar dirancang dengan tepat, artinya, materi ajar yang disampaikan sesuai dengan tujuan pembelajaran dan karakteristik peserta didik serta kemandirian belajar peserta didik. Model pembelajaran web dipandang sesuai dengan tuntutan kompetensi pembelajaran era 21 , karena peserta didik aktif mencari materi ajar berdasarkan instruksi yang diberikan oleh pendidik. Oleh karena itu, model pembelajaran berbasis web dengan karakteristik strategi penyampaian Web Course, Web Centric Course, Web Enhanced Course (Rusman,2013). Dengan demikian, pemanfaatan internet berbasis web menjadi kebutuhan, agar peserta didik mampu mengembangkan potensi dirinya berdasarkan harapan dan keinginannya untuk tetap eksis di masa datang.

\section{PEMBAHASAN}

Kegiatan pembelajaran harus dirancang menghubungkan antara pengalaman peserta didik dengan masalah dunia nyata, mengubah fokus mereka dalam proses belajar. Jika peserta didik memiliki kesadaran tinggi akibat dari perubahan global, antara apa yang dipelajari di kelas dengan kondisi nyata merupakan masalah penting bagi mereka, maka motivasi mereka akan meningkat, oleh karena itu, pendidik mampu menciptakan kegiatan pembelajaran dengan memanfaatkan berbagai sumber belajar dengan strategi konteksnya sesuai dengan kehidupan peserta didik/mahasiswa, maka prestasi akademik dan keterampilan berpikir kritis dan prestasi akademik meningkat. Fokus aktivitas yang diharapkan terjadi dalam proses pembelajaran adalah (1) jalin hubungan baik dalam pembelajaran yang berkualitas dan kuat, serta saling 
menghormati dan saling menjaga kepercayaan. Kembangkan model pembelajaran yang berfokus pada peserta didik (Project Based Learning, Problem Based Learning, dan pembelajaran berbasis internet/e-learning).

\section{Pembelajaran} era menempatkan peserta didik sebagai objek belajar dan rancangan pembelajaran yang digunakan mampu mengembangkan keterampilan berupa bekerja sama/ kolaboratif, kreatif, inovasi, dan pemecahan masalah serta berpikir kritis. Keterampilan ini memberikan arah dan pandangan belajar agar mereka mampu beradaptasi dan bekerja di masa datng, tanpa menimbulkan kebimbangan dan ketidak suksesan dan mampu menjalani ketahanmalangan. .

Model pembelajaran mengunakan internet sebagai strategi penyampaian dapat memperhatikan fungisi dan karakteristiknya seperti; (a) Web Course dengan penggunaan internet untuk keperluan pendidikan, mahasiswa dan dosen sepenuhnya terpisah dan tidak diperlukn adanya tatap muka. Seluruh bahan ajar, diskusi, konsultasi, penungasan, latihan, ujian, dan kegiatan pembelajaran lainnya sepenuhnya disampaikan melalui internet. Dengan kata lain model ini menggunakan sistem jarak jauh, (b) Web Centric Course, penggunaan internet memadukan antara belajar jarak jauh dan tatap muka dan sebagian materi disampiakan melalui internet, dan sebagaian lagi melalui tatap muka, (c) Web Enhanced Course, penggunaan internet peningkatan kualitas pembelajaran yang dilakukan di kelas. Fungsi internet adalah untuk memberikan pengayaan dan komunikasi antara mahasiswa dengan dosen, sesame mahasiswa, anggota kelompok, atau mahasiswa dengan nara sumber lain. Peran dosen i dituntu untuk menguasai teknik mencari informasi di internet, membimbing mahasiswa mencari dan menemukan situs-situs yang menarik dan diminati, melayani bimbingan dan komunikasi melalui internet, dan kecakapan lain yang diperlukan.

Pembelajaran era 21 menuntut capaian pembelajaran yang berpijak pada empat keterampilan dasar yaitu kolaboratif, komunikasi, berpikir kritis dan kreatif serta didukung visi pembelajaran; learning to know, learning to do, learning to be, dan learning to live together dengam memperhatikan literasi data, literasi TIK, dan literasi sosial/manusia.

\section{KESIMPULAN DAN SARAN}

$\begin{array}{lll}\text { Pembelajaran era } & 21\end{array}$ mempersiapkan peserta didik atau mahasiswa menjadi warga Negara yang baik dan unggul merupakan perjuangan. Penggunaan teknologi internet, kompetesi lokal dan internasional serta lingkungan sosial mutlak diperlukan sebagai pengalaman belajar. Perlu dilakukan pendekatan baru dengan memperhatikan karakteristik peserta didik, sejak mulai tahap awal pembelajaran hingga sarjana tidak perlu menunggu sampai mereka menghadapi DUDI. Ini menjadi kajian yang mendalam melalui penelitian empirik pada pendidikan teknik elektronika untuk mengembangkan bahan ajar, model dan strategi pembelajaran menghadapi pembelajaran era 21 . 
Saran, setelah mengetahui informasi dalam artikel secara sekilas, perlu dilakukan kajian melalui penelitian terkait keterampilan era 21. Saat ini lembaga kajian dalam bentuk jurnal Problems of Education in the $21^{\text {st }}$ Century. Mari kita diskusikan bersama dan memberi informasi tentang keterampilan era 21. Agar capaian luaran pembelajaran dapat di laksanakan peserta didik atau mahasiswa FT UNM.

\section{PENUTUP}

Adopsi model pembelajaran era 21 yang telah dikemukakan, sebaiknya setiap rancangan pembelajaran yang digunakan menggunakan pijak komponen keterampilan era 21 dan visi pembelajaran berbasis era pengetahuan dengan mengintegrasikan penggunaan teknologi informasi dan komunikasi dengan model strategi penyampaian $e$ learning secara langsung (synkronous) maupu tidak langsung (a-synkronous).

\section{DAFTAR PUSTAKA}

Ajeyelemi,.1993. Teacher Strategies Used by Exemplary STS Theacher. What Research Says to Science Teaching. Washington DC: National Science Teacher Asossiation.

Ananiadou, K. Claro,. 2009. $21^{\text {st }}$ Century Skils and Competences for new Millennium Learners in OECD Education Working Papers. No. 41. Paris, OECD Publishing.

Barry,.2012,. What Skill will you need to succeed in the future? Phonex Forward (online) Tempe, AZ,. University of Phoenix.

Delors, J. Al Mufti, at.al, 2015,. Learning: The Treasure Within:
Report to UNESCO of the International Commison on Education for the Twenty-First Century` Paris, UNESCO.

Griffin, P. McGraw, B. and Care, E. (eds),. 2012. Assesment and Teaching of 21st Century Skills Dodrecht, NL, Springer.

Lies,.Challenges for the future of Learning until 2030: Foresight on Learning, Innovation and Creativity: Presentation at LearnTec 2010, Karlsruhe, DE.

Litbang Dikbud, Pergeseran Paradigma Belajar Abad 21. Badan Penelitian dan Pengembangan Kementrian Pendidikan dan Kebudayaan, http://litbang.kemendikbud.go.id/sit e/index.php/home2-4-pergeseranparadikma-belajar-adab-21. (diakses. 16 Agustus 2019).

Mohammed Anine Chatti. The Web 2.0 Driven SECI Model Based Learning Proses. http://mohamedaninechatti.blogspot .com. Diakses 16 agustus 2019.

Mohammed Anine Chatti. The Web 2.0 Driven SECI Model Based Learning Proses. http://mohamedaninechatti.blogspot .com.

Rusman, Deni Kurniawan, Cepi Riyana,. 2013. Pembelajaran berbasis teknologi Informasi dan Komunikasi: Mengembangkan Profesionalitas guru. Jakarta: PT. Raja Grafindo.

Savenda, A. and Apfer,. 2011. Teaching and Learning $21^{\text {st }}$ Century Skills: Lesson from the Learning Science. A Global Cities Education Network Report. New York: Asia Asociety.

Scoot,. 2015. The Futures of Learning: Why must learning content and methods change in the $21^{\text {st }}$ century? 
UNESCO Education Research and Foresight, Paris. [ ERF Working Papers Series, Namber 13].

Trilling, B and Hood Fadel,.2009. 21 $1^{\text {st }}$ Century Skills: Learning for Life in Our Times. San Fransisco Calif,. Jassey-Bass-John Wiley \& Sons, Inc.

Wagner, T, 2010,. Overcoming The Global Achivement Gap (online). Cambridge, Mass,. Harvard University.

Waras Kamdi,. 2008. Project Based Laerning: Pendekatan Pembelajaran Inovatif. Universitas Negeri Malang. 